\title{
Biomass and Forage Production from Reclaimed Stripmined Land and Adjoining Native Range in Central Wyoming
}

\author{
ROBERT LANG
}

\begin{abstract}
Aboveground biomass and forage production from native range and adjacent reclaimed stripmined land were measured in 1977. On 2 of the 4 native range transects the aboveground biomass was greater than on reclaimed areas, largely due to big sagebrush and mat-forming species. Forage production, defined as the vegetation consumed by domestic grazing animals on properly grazed range, was equal to or greater on the reclaimed land than on adjoining native range.
\end{abstract}

Reclamation of stripmined lands is required by both the Wyoming Department of Environmental Quality and by recently (1977) enacted federal legislation. In both instances "production" of vegetation equal to, or greater than, that of the pre-mined condition is one of the requirements of the laws and regulations promulgated by the enforcement agencies.

Interpretation of the term production is variable. To some it means total aboveground biomass regardless of whether or not it is usuable by grazing animals, and to others it carries the connotation of "forage" that can be utilized.

During the summer of 1977 a study was initiated near Glenrock, Wyo., to compare biomass and "forage" production from undisturbed native range with that from adjacent lands which had been reclaimed after stripmining for coal production.

\section{Description of the Area}

The study area lies near the southern edge of the Powder River Basin. The native range is quite variable with some areas supporting almost pure stands of herbaceous species and others with variable stands of shrubs (primarily big sagebrush, Artemisia tridentata) and succulents or mat-forming species such as plains pricklypear (Opuntia polyacantha) and hooker sandwort (Arenaria hookeri). The most common vegetation type is sagebrush-grass and this type was selected for sampling to determine aboveground biomass and "forage" production.

In accordance with Wyoming laws, rules, and regulations, the topsoil is removed from the land prior to mining and is then spread over reshaped soil and seeded to reclaim the land to its previous major use, which in this study was for grazing of domestic livestock.

After the mining operation has progressed for a few years, there is a new acreage of mined-out land to be reclaimed each year. Sometimes the land to be reclaimed is ready for seeding in the fall and at other times it is not ready for seeding until spring.

Four areas of reclaimed land were sampled in this study. Area A was seeded in the spring of 1973 with a mixture of $9 \mathrm{lb}$ of Fairway crested wheatgrass (Agropyron cristatum), $3 \mathrm{lb}$ of western wheatgrass (Agropyron smithii), and $3 \mathrm{lb}$ of thickspike wheatgrass (Agropyron dasystachyum) per acre. Five growing seasons had

\footnotetext{
Author is Professor Emeritus Division of Range Management, College of Agriculture, University of Wyoming, Laramie 82071

Manuscript received December 11, 1980.
}

elapsed prior to sampling.

Areas B, C, and D were all seeded with $6 \mathrm{lb}$ of Fairway crested wheatgrass, $6 \mathrm{lb}$ of Nordan crested wheat grass (Agropyron desertorum) and $3 \mathrm{lb}$ each of western wheatgrass and thickspike wheatgrass per acre. From these figures it may be noted that the 1973 seeding was $60 \%$ and the 1975 seedings were $67 \%$ introduced species. Areas B and C were seeded in the fall of 1975 and only 2 growing seasons had elapsed prior to sampling. Area $D$ was seeded in the spring of 1974, thus having completed 3 growing seasons prior to sampling.

\section{Methods}

Four transects, each 10 l-meter square plots, were established at random in the sagebrush-grass vegetative type which was the major native range type and 4 transects, each 10, 1-meter square plots on adjacent reclaimed land. One transect was established on each of the 4 reclaimed areas described above.

The vegetation within each meter square plot was clipped and bagged separately by species. Herbaceous species were clipped at ground level. Approximate current year's growth was harvested from sagebrush. All plant material was oven-dried at $70^{\circ} \mathrm{C}$ for 24 hours (excepting plains pricklypear, which was dried for 72 hours) and then weighed to the nearest $.01 \mathrm{gm}$. These data were then converted to $\mathrm{kg} / \mathrm{ha}$ to determine above ground biomass. To determine "forage" production, the biomass weight of each species was multiplied by its appropriate proper use factor ${ }^{l}$ which considers what percentage of each species will be consumed by the major grazing animal species under proper utilization of these range resources.

\section{Results and Discussion}

Aboveground biomass from native range varied from 714.6 to 373.5 and averaged $570.9 \mathrm{~kg} / \mathrm{ha}$, largely in response to the amount of big sagebrush present on the harvested plots.

On the reclaimed areas the aboveground biomass varied from $861.1 \mathrm{~kg} / \mathrm{ha}$ on land seeded in the spring of 1973, to $270.2 \mathrm{~kg} / \mathrm{ha}$ on one of the areas seeded in the fall of 1975. Biomass data by vegetation groups are presented in Table 1.

Forage production as defined above, was calculated for both native range and reclaimed areas. On the native range the forage production from the 4 transects ranged from 137.1 to 113.0 and averaged $124.9 \mathrm{~kg} / \mathrm{ha}$. On the reclaimed lands the forage production ranged from 426.0 to $128.6 \mathrm{~kg} / \mathrm{ha}$. Data pertaining to forage production by vegetative groups are also presented in Table 1 . It is interesting to note that the greatest aboveground biomass and the greatest forage production from reclaimed land were from areas seeded in the spring of the year (spring 1973 and spring 1975). The

1 Proper use factors used were those commonly used by SCS, that is, $50 \%$ of perennial grasses and $10 \%$ of big sagebrush. Cacti, mat-forming species, a nnual grasses, etc., are normally not used on properly grazed range. 
Table 1. Average above ground biomass and foragel production from native range and from four adjacent reclaimed areas Glenrock, Wyo. Vegetation clipped in August, 1977. Data in terms of $\mathrm{kg} / \mathrm{ha}$ oven dry.

\begin{tabular}{|c|c|c|c|c|c|c|c|c|c|c|}
\hline \multirow[b]{2}{*}{ Vegetation ${ }^{2}$ groups } & \multicolumn{2}{|c|}{ Native range } & \multicolumn{2}{|c|}{ Area A-Seeded } & \multicolumn{2}{|c|}{ Area B-Seeded } & \multicolumn{2}{|c|}{ Area C-Seeded } & \multicolumn{2}{|c|}{ Area D-Seeded } \\
\hline & $\begin{array}{c}\text { Biomass } \\
\text { Wt }\end{array}$ & $\begin{array}{c}\text { Forage } \\
\mathrm{Wt}\end{array}$ & $\begin{array}{c}\text { Biomass } \\
W_{t}\end{array}$ & $\begin{array}{c}\text { Forage } \\
\mathrm{Wt}\end{array}$ & $\begin{array}{c}\text { Biomass } \\
\text { Wt }\end{array}$ & $\begin{array}{c}\text { Forage } \\
\mathrm{Wt}\end{array}$ & $\begin{array}{c}\text { Biomass } \\
\mathrm{Wt}_{\mathrm{t}}\end{array}$ & $\begin{array}{c}\text { Forage } \\
\mathrm{Wt}\end{array}$ & $\begin{array}{c}\text { Biomass } \\
\mathrm{Wt}\end{array}$ & $\begin{array}{c}\text { Forage } \\
\mathrm{Wt}\end{array}$ \\
\hline Introduced perennial grasses & - & - & 713.6 & 356.8 & 247.5 & 123.8 & 194.6 & 97.3 & 603.8 & 301.9 \\
\hline Native perennial grass and grasslike plants & 197.9 & 99.0 & 138.3 & 69.2 & 9.6 & 4.8 & 63.8 & 31.9 & 27.8 & 13.9 \\
\hline Annual grasses & 0.2 & - & 4.0 & - & 15.2 & - & 0.2 & - & 0.4 & - \\
\hline Big sagebrush & 258.5 & 25.9 & $\ldots$ & - & - & - & - & - & - & - \\
\hline $\begin{array}{l}\text { Forbs, halfshrubs and shrubs other than big } \\
\text { sagebrush } \\
\text { Total }\end{array}$ & $\begin{array}{l}114.3 \\
570.9\end{array}$ & $\overline{124.9}$ & $\begin{array}{r}5.2 \\
861.1\end{array}$ & $\overline{426.0}$ & $\begin{array}{r}17.5 \\
289.9\end{array}$ & $\overline{128.6}$ & $\begin{array}{r}11.6 \\
270.2\end{array}$ & $\overline{129.2}$ & $\begin{array}{r}23.0 \\
655.0\end{array}$ & $3 \overline{5} .8$ \\
\hline
\end{tabular}

' Forage is considered to be the aboveground biomass consumed by domestic grazing animals under proper grazing management.

${ }^{2} \mathrm{All}$ species encountered on native range and reclaimed areas are listed in Appendix $\mathrm{A}$.

Table 2. Monthly and annual precipitation (inches) for the years 1973 through 1976 at Glenrock, Wyo. (5 E S E).

\begin{tabular}{rccccccccccccc}
\hline \hline & Jan. & Feb. & Mar. & Apr. & May & June & July & Aug. & Sept. & Oct. & Nov. & Dec. & Departure Ann. from Nor. \\
\hline 1973 & .84 & .28 & 1.33 & 5.67 & .90 & .46 & 4.16 & .35 & 5.43 & .31 & .59 & .48 & $20.80+7.89$ \\
1974 & .36 & .57 & .25 & 1.78 & .30 & .00 & .50 & 1.00 & .80 & 1.00 & .56 & .03 & $7.00-5.91$ \\
1975 & .16 & .25 & 3.02 & .24 & 2.24 & 1.16 & .54 & 1.07 & .45 & 1.42 & .31 & .85 & $11.71-1.20$ \\
1976 & .15 & .39 & .29 & 3.19 & 3.84 & 1.57 & .67 & .12 & 1.70 & 1.50 & .09 & .08 & $13.59+.68$ \\
\hline
\end{tabular}

lowest were from the two areas seeded in the fall of 1975.

However, 1973 was a year with abundant precipitation, being nearly 8 inches above normal. 1975 precipitation was below normal for the year but precipitation from March through June was good. The areas seeded in the fall of 1975 would probably not have seedling emergence until the spring of 1976. Precipitation from April through June of 1976 was very good and the total for the year was .68 inches above normal. Monthly and annual precipitation data from 1973 through 1976 are presented in Table 2.

It was found that crested wheatgrass and desert wheatgrass, which varied from 60 to $67 \%$ of the seed planted on the reclaimed land, accounted for $83.2 \%$ of the biomass on all seeded areas and made up $86.4 \%$ of the total forage production.

On the native range big sagebrush was $45.3 \%$ of the total aboveground biomass and $20.7 \%$ of the forage production, whereas perennial grass and grass-like species were $34.7 \%$ of the total aboveground biomass and $79.3 \%$ of the forage production. From these figures it may be noted that slightly over $20 \%$ of the total aboveground biomass was from species that contributed nothing as forage because they are not utilized on properly grazed range.

From the forage production figures it is possible to calculate grazing capacity for both the native range and reclaimed land. Considering that 1 ton ( 2.24 metric $T)$ of hay will support an animal unit for 3 months, it would require $302.7 \mathrm{~kg}$ of hay equivalent to furnish grazing for 1 animal unit for 1 month.

The average forage production of oven-dry material from the native range sampled was $124.8 \mathrm{~kg} / \mathrm{ha}$. With hay at $12 \%$ moisture, this would convert to $139.8 \mathrm{~kg}$ of hay equivalent per hectare. For 1 AUM $302.7 \mathrm{~kg}$ are required; thus the grazing capacity of the native range sampled would be 2.17 ha per $\triangle U M$.

The same procedure applied to the reclaimed areas would show an average production from the 4 areas sampled to be $249.9 \mathrm{~kg}$ of forage per ha oven dry. This would convert to $279.9 \mathrm{~kg}$ of hay equivalent per hectare and an average grazing capacity of essentially 1.1 ha per AUM based on these averages.

\section{Conclusions}

From this study one may conclude that crested wheatgrass and desert wheatgrass are very well adapted to the area. On the reclaimed areas they furnished the greatest part of the aboveground biomass as well as forage production at least during the first 5 growing seasons after seeding. A number of native species are invading the seeded area. Only 3 species were seeded in Area A (the oldest seeded area) but 13 species were present when it was sampled. Four species were seeded and 7 to 10 species were present when the newest seeded areas were sampled. This species diversity compares with 12 as the highest and 8 as the smallest number of species encountered on the 4 transects in native range.

Spring seeded areas were more productive than fall seeded areas in this study. However, the results may have been due to precipitation and other climatic factors in the year of seeding and further comparisons of spring vs. fall seeding should be made before definite conclusions are drawn.

It may be concluded that if "production" is considered to be forage or grazing capacity, these types of land may be successfully reclaimed. However, when crested wheatgrass and/or desert wheatgrass are the major species, special management is required as both are utilized best in early spring and late fall. Areas which are predominately crested or desert wheatgrass may need to be fenced and grazed during their periods of optimum palatability particularly where they are a relatively small part of a total management area.

\section{Appendix A}

List of scientific and corresponding common names of species found on sample plots in this study.

\begin{tabular}{ll} 
Agropyron cristatum & Crested wheatgrass \\
A. dasystachyum & Thickspike wheatgrass \\
A. desertorum & Desert wheatgrass \\
A. elongatum & Tall wheatgrass \\
A. smithii & Western wheatgrass \\
A. spicatum & Bluebunch wheatgrass \\
A. trachycaulum & Slender wheatgrass \\
Arenaria hookeri & Hooker sandwort \\
Artemisia frigida & Fringed sagewort \\
A. tridentata & Big sagebrush \\
Astragalus spp. & Loco \\
Bouteloua gracilis & Blue grama grass \\
Bromus tectorum & Hairy chess \\
Carex eleocharis & Needleleaf sedge \\
Carex filifolia & Threadleaf sedge \\
Chrysothamnus vicidiflorus & Green rabbitbrush \\
Hordeum jubatum & Green foxtail \\
Koeleria cristata & Junegrass \\
Opuntia polyacantha & Plains pricklypear \\
Oryzopsis hymenoides & Indian ricegrass \\
Poa secunda & Sandberg bluegrass \\
Stipa comata & Needleandthread \\
S. viridula & Green needlegrass \\
Vulpia octoflora & Sixweeks fescue \\
\hline
\end{tabular}

